\title{
Unpacking Social Entrepreneurship: Exploring the Definition Chaos and Its Consequences in England
}

\author{
Tanja Collavo
}

\begin{abstract}
Socialentrepreneurship has always been a contested concept, both within the academic discourse and in practice. A lot of scholarly effort has been put into analyzing the different definitions of social entrepreneurship and the negative consequences that the definitional debate has on the opportunity to advance social entrepreneurship as a research field. Very little is known about what the consequences of the multiple meanings of social entrepreneurship are for people working in the sector. This paper advances knowledge on this topic by looking at the social entrepreneurship sector in England and by investigating through qualitative research methods what sector members think about social entrepreneurship and its unclear boundaries. The results show that there are three different conceptions of social entrepreneurship within the sector in England. However, while everyone agrees on the presence of a definitional debate, opinions on what this means for the sector are several. Some members think it is something positive; some others think it is causing different issues, and a third group considers it as irrelevant.
\end{abstract}

Keywords: social entrepreneurship, definitions, social enterprises, social entrepreneurs, UK, England.

\section{INTRODUCTION}

Social entrepreneurship is a phenomenon that has existed for centuries (Sepulveda, 2015). It has taken the form of either not-for-profits and nongovernmental organizations (NGOs) engaging in trade to support their activities, or of businesses looking after their employees' welfare (Alter, 2007; Sepulveda, 2015; Teasdale, 2012). Furthermore, it has been additionally represented by the new organizational forms surging in different countries

1 Tanja Collavo, DPhil (PhD candidate), Said Business School, Oxford University New College, Holywell Street, OX1 3BN Oxford (UK); e-mail: tanja.collavo@new.ox.ac.uk. 
in the '70s, such as cooperatives and micro-credit institutions (Alter, 2007; Grenier, 2009). Nonetheless, the term "social entrepreneurship" has been in use only for the last 20-25 years, generated by think-tanks, foundations and politicians prevalently based in the U.S. and in the UK (Bacq \& Janssen, 2011; Grenier, 2008; Teasdale, 2012).

Ever since, many articles have been published discussing both the shortcomings of the lack of scholars' agreement on the meaning of social entrepreneurship and the schools of thought that created this situation (Alter, 2007; Bacq \& Janssen, 2011; Choi \& Majumdar, 2013; Dacin, Dacin \& Matear, 2010; Defourny \& Nyssens, 2010; Hoogendoorn, Pennings \& Thurik, 2010; Perrini, 2006). The lack of agreement around a definition of social entrepreneurship is not only academic but also practice-driven (Grenier, 2008; Martin \& Osberg, 2007; Nicholls, 2010; Teasdale, 2012). So, why are there so many different definitions of social entrepreneurship in the world of practice? What are the practical consequences, if any, of the presence of multiple conceptions of social entrepreneurship? For the purpose of this paper, social entrepreneurship will be defined as any action combining the pursuit of social impact with entrepreneurial techniques or business models (Austin, Stevenson \& Wei-Skillern, 2006; Bacq \& Janssen, 2011; Corner \& Ho, 2010).

While the existing literature has already developed many explanations for the pre-paradigmatic state of the sector (Lehner \& Kansikas, 2013; Nicholls, 2010), its focus has prevalently been conceptual rather than empirical (Dacin et al., 2010). Consequently, the scholarly focus has concentrated on the institutional causes of the definitional confusion rather than on the organizational ones. Moreover, very few authors have looked at what the consequences of this situation are for social entrepreneurs, social enterprises, social investors or policy makers. This has generated an important knowledge gap to be addressed. Indeed, it is possible to assume that the lack of a definition does have an impact, at least on the search for talent, on policy making (Peredo \& McLean, 2006) and on organizational strategies and tactics (Dey \& Teasdale, 2016).

This paper addresses this gap by using as a setting the social entrepreneurship sector in England. This is considered as one of the most advanced in the world (Villeneuve-Smith, Temple, Brown, Gregory, \& BMG Research, 2015) and - being subject to influences from the US., the European Union and its own public and private players - it displays a wide variety of conceptions of social entrepreneurship (Huckfield, 2014; Sepulveda, 2015). Therefore, it represents a good setting to explore the long-term consequences on multiple stakeholders of the presence of different definitions of social entrepreneurship, social entrepreneurs and social enterprises. 
The paper is organized as follows. Firstly, it outlines the existing descriptions of social entrepreneurship present in academic papers and their consequences on the advancement of scholarship on the topic as well as on the sector. The next section describes why England was chosen as the setting and how data was gathered from the multiple stakeholders present in the sector. Finally, the paper presents the definitions of social entrepreneurship traced in England and the impact that their multiplicity has on the development of the sector and on its various stakeholders.

\section{LITERATURE REVIEW}

\section{The multiple definitions of social entrepreneurship}

Social entrepreneurship is intrinsically a difficult phenomenon to pin down and describe. Its very nature calls for a combination of institutional logic and activities typical of both the public and business sectors (Lehner \& Kansikas, 2013). As a consequence of such hybridity, it is a concept usually context-related and expressed through very different organizational forms and practices (Huybrechts \& Nicholls, 2012; Kerlin, 2013).

Social entrepreneurs and enterprises operate in a broad range of sectors: from arts and culture to banking, from real estate development to agriculture (Alter, 2007; EKOS, 2014). Furthermore, their hybrid nature can manifest itself as: the solution of challenging problems through innovation; the creation of employment opportunities and/or of skills development for marginalized or disadvantaged people and communities; the creation of businesses and trading activities that generate social impact (Achleitner, Spiess-Knafl, Lutz \& Mayer, 2012; Garrow \& Hasenfeld, 2014; Martin \& Osberg, 2007; Vasi, 2009). This variety makes it difficult to circumscribe the phenomenon, since this may cause the exclusion of essential projects and innovative solutions.

Austin et al. (2006) divided social entrepreneurship definitions between narrow and broad. Narrow definitions limit social entrepreneurship to the application of business activities and skills to organizations active in the third-sector. Broader definitions include within the social entrepreneurship umbrella the whole spectrum of activities from businesses' CSR practices to innovation and entrepreneurialism in NGOs and charities. Looking at what was happening in-between such a wide spectrum, Dacin et al. (2010) identified 37 different definitions of social enterprises and social entrepreneurs, based on multiple dimensions such as innovativeness, creation of social change, embeddedness in a specific community, adoption of virtuous entrepreneurial behaviors, diffused ownership and financial sustainability. The only common trait among these definitions appeared to be the description of social 
entrepreneurs and enterprises as mobilizers of resources, primarily for the creation of a positive social and/or environmental impact (Dacin et al., 2010; Huybrechts \& Nicholls, 2012) and the association of social entrepreneurship with optimism, social change and the creation of a fair and sustainable society (Dey \& Steyaert, 2010).

\section{Origins of the definitional debate}

The multiplicity of conceptions of social entrepreneurship can be traced back to the different theories on what problems it tries to solve (Bacq \& Janssen, 2011; Huybrechts \& Nicholls, 2012). For example, according to some foundations and network organizations such as Ashoka, the remit of social entrepreneurship is to firstly change the citizen sector by making it more efficient and entrepreneurial and then to change the entire society by tackling unjust equilibria (Ashoka UK, 2015; Drayton, 2006; Sen, 2007). For the European Union, instead, social enterprises should be a mechanism to foster citizens' democratic participation in the management of businesses, to revitalize the economy of poorer countries and to improve the employability of marginalized people (Bacq \& Janssen, 2011; Borzaga \& Defourny, 2001; Defourny \& Nyssens, 2010). Different theories of change inevitably lead to different roles attributed to social entrepreneurs and enterprises and, thus, to a stronger or weaker focus on some of their characteristics.

Such a diversity of conceptions is also reinforced by the different cultures, phases of economic development and social contexts of the countries where social entrepreneurship exists as a sector (Kerlin, 2013). Countries, whose first experience with social entrepreneurship was connected with the cooperative movement, prevalently see social entrepreneurship as connected to the shared ownership of economic activities. On the contrary, countries with an individualistic and entrepreneurial culture often gave rise to definitions of the phenomenon based on its disruptiveness (Defourny \& Nyssens, 2010; Kerlin, 2013) or on the need of no-profits to become financially sustainable through trade (Kerlin, 2013; Sepulveda, 2015). Within each geographical context, the definitional debate is usually also further complicated by the presence of several public and private organizations and sometimes even of the government (Kerlin, 2013; Sepulveda, 2015) interested in the sector. In several cases, indeed, organizations operating in the same setting have very different views of social entrepreneurship and on which part of the sector should be given the most attention (Dacin et al., 2010; Huybrechts \& Nicholls, 2012; Nicholls, 2010; Peredo \& McLean, 2006).

Finally, the definitional debate has been constantly revitalized in the last 15-20 years by scholars' interest in it. Several authors have discussed the presence of two, three or sometimes even four schools of thought around 
social entrepreneurship (Dees \& Anderson, 2006; Defourny \& Nyssens, 2010; Hoogendoorn et al., 2010; Mair \& Martí, 2006; Peredo \& McLean, 2006), with the majority agreeing on a "three schools" split. The first school of thought looks at social entrepreneurship as the undertaking of revenue-generating activities from the side of no-profit organizations or as management strategies to create social value. The second school of thought interprets social entrepreneurship in a Schumpeterian tradition, highlighting its innovative side in the pursuit of poverty alleviation and social equality. Finally, the third school of thought investigates social entrepreneurship as the activity of organizations aiming to benefit their own community (Defourny \& Nyssens, 2010; Mair \& Martí, 2006). Most of the studies produced by the different schools have either employed anecdotal evidence or were conceptual. This favored the creation of multiple definitions based on the specific organization or individual analyzed or on the theory developed (Dacin et al., 2010; Hill, Kothari \& Shea, 2010; Peredo \& McLean, 2006).

\section{Consequences of the definitional debate}

Whether created by scholars or practitioners, the multiplicity of conceptions around social entrepreneurship generates tensions and debates on the appropriateness of the existing organizational forms and practices, the location of sector boundaries and the best role for the sector in the wider economic environment (Bacq \& Janssen, 2011). These tensions, in turn, create multiple accepted practices within the sector in three core dimensions - leadership, structure and business model.

With regard to leadership, there are two possible conceptions of social entrepreneurship: one based on concentrated leadership and one based on diffused leadership. Concentrated leadership focuses on the figure of the social entrepreneur, described as an inspiring lone hero, who comes up with novel solutions and relentlessly pursues them (Martin \& Osberg, 2007). Alternatively, it can be applied to organizations pursuing a social object through a traditional corporate or shares-based structure. Diffused leadership is instead the characteristic trait of social enterprises that either have distributed ownership or are seen as part of a community network that, as a whole, achieves social change (Bacq \& Janssen, 2011; Defourny \& Nyssens, 2010).

As far as the legal structure is concerned, the potential forms of social entrepreneurship are several. In some countries, such as the US. or the UK, a specific legal structure exists for the incorporation of those organizations that see themselves as social enterprises (Huybrechts \& Nicholls, 2012). However, this form is not exclusive (i.e., social enterprises can incorporate through different legal forms - from charities to companies limited by shares) 
and, in reality, it is usually adopted by a very small percentage of organizations (Haigh, Walker, Bacq \& Kickul, 2015). In other countries, such as France, Italy, Germany or Spain, the cooperative form appears to be the privileged one for the signaling of a social enterprise status (Defourny \& Nyssens, 2010). In general, in most countries, a social entrepreneurial organization can legally take any form, (Bacq \& Janssen, 2011). Its identification and differentiation from more traditional organizations, therefore, relies on other vehicles such as marketing, campaigning or badges. Furthermore, many options exist for social entrepreneurial ventures even with regard to organizational structure. Indeed, the co-existence of its business-related and social-related activities can happen through integration (when the two produce one another), partial overlap, or complementarity (when business activities generate revenues that sustain the unrelated social-oriented activities) (Alter, 2007; Fowler, 2000).

Finally, with regard to the business model, social entrepreneurial activity is usually placed on a spectrum going from purely nonprofits, engaging in innovative or revenue-generating activities to businesses producing social or environmental impact as a part of their core operations (Alter, 2007). At the one extreme of the spectrum, there are some of the social entrepreneurs supported by organizations such as Ashoka, the Skoll Foundation or the Schwab Foundation, starting innovative no-profits to achieve social change, and no-profits engaging in revenue-generating activities (e.g., Oxfam). On the other side of the spectrum, there are social enterprises like Belu Water or Divine Chocolate, which are businesses whose aim is to be profitable and financially sustainable, but which are also characterized by shared ownership and/or an entrenched social mission driving all their activities. In-between these typologies there are multiple hybrid forms of organizing, blending their social and business sides in very different ways.

In summary, the definitional debate around social entrepreneurship has its origins in both the academic field and in the practices of organizations describing themselves as members of the social entrepreneurship sector. The analysis of its consequences has thus far focused on its impact on scholarly knowledge of the sector (Alter, 2007; Bacq \& Janssen, 2011; Choi \& Majumdar, 2013; Dacin et al., 2010; Defourny \& Nyssens, 2010) and on the choices available for social entrepreneurs and enterprises on leadership, legal structure, organizational structure and social impact/business model. Considerations on what the definitional debate means for the building of the social entrepreneurship sector appear to be missing (Hoogendoorn et al., 2010). Addressing this gap calls for examining the reactions of multiple stakeholders to the definitional debate and an analysis of how the latter affects the delivery of the support that social entrepreneurs and enterprises need to thrive. This paper will do so by focusing on a specific sector created around social entrepreneurship and by 
presenting evidence concerning the impact of the definitional debate on the practices and players present in it.

\section{RESEARCH METHODS}

A case study design was chosen for this project because it creates the possibility to look at the object of inquiry from the perspectives of multiple actors operating within the same setting and to have an in-depth understanding of how their activities and views are formed (Huberman \& Miles, 2002). The UK was initially chosen as an ideal research setting because, despite having one of the most advanced social entrepreneurship sectors in the world (Defourny \& Nyssens, 2010; Hoogendoorn et al., 2010; Nicholls, 2010; Teasdale, 2012), it is still characterised by a lively debate about the meaning of social entrepreneurship. However, after a first preliminary study, it became apparent that the social entrepreneurship sector was extremely variable and at different stages of development in England, Scotland, Wales and Northern Ireland (Hazenberg, Bajwa-Patel, Roy, Mazzei \& Baglioni, 2016; interviewees of this study; 2015). Each nation has different organizations influencing the sector and operating in it, is subject to different political priorities, and attributes to social entrepreneurship a different meaning (Hazenberg et al., 2016). Furthermore, according to some interviewees and people contacted for the study, while the social entrepreneurship sector has constantly grown in both England and Scotland, it is still in a relatively emerging phase in Wales and Northern Ireland.

Ultimately, England was preferred over Scotland as a case study due to several reasons. First of all, there is more research, and there are more publications - both academic and non-academic - about England than about Scotland. This was expected to facilitate data collection and an in-depth understanding of all the actors and influences at play. Secondly, England's social entrepreneurship sector is extremely inclusive and comprises of members from all the traditional sectors (businesses, government and charities), together with many organizations created on purpose to support its development (e.g., social entrepreneurship-related intermediaries and social investors) (Grenier, 2008; UK government, 2015). This ensures the presence of many institutional players pursuing different goals with regard to the sector's role and conception. Thirdly, thanks to being the seat of the UK government, England is the nation where most government efforts have been put into developing the social entrepreneurship sector (Alcock, 2010; Sepulveda, 2015; Teasdale, 2012). Moreover, it is the country where both American and European conceptions of this phenomenon managed to 
penetrate, probably thanks to its cultural proximity to both (Sepulveda, 2015; Teasdale, 2012), to the presence of international organizations in London (Grenier, 2008) and to some of its universities operating as international conduits of ideas (Benjamin, 2004; Teasdale, 2012; Young, 2004). These characteristics were expected to make England a good "micro-area" to study the confusion around the meaning of social entrepreneurship that is experienced at the global level.

\section{Data collection and analysis}

With the setting established, data collection proceeded in two different phases. In the first one, data was gathered and employed to analyze the development of the social entrepreneurship sector in England, from its appearance (the late 1990s) to 2016. In this phase, archival data was the primary source of information and it consisted of newspaper and magazine articles published in the period 1995-2016, academic papers discussing social entrepreneurship in England and relevant reports produced by the government and national think-tanks. For example, articles were retrieved from social-entrepreneurship-related outlets, such as Third Sector (20002016) or Regeneration and Renewal (2000-2016), national and international media (e.g., The Guardian, The Economist, and The Times), local newspapers or academia-related magazines such as the Stanford Social Innovation Review. The different types of archives were gathered using searches on databases such as Factiva, Nexis UK, Business Source Complete and Google Scholar, using as key-words "social entrepreneur," "social entrepreneurship" and "social enterprise" and restricting the search to documents published in England or discussing England in the period 1995-2016. Additionally, reports and academic papers were retrieved starting from their reference in existing work, either academic or non-academic, or following the suggestions of sector experts that were contacted for this purpose.

This data was analyzed according to a historical method (Barley \& Tolbert, 1997; Zietsma \& Lawrence, 2010), aimed at recreating the state of social entrepreneurship in England at different points in time. Data were grouped according to its publication date and then commonalities and discrepancies were searched for among documents belonging or referring to events in the same time period. Such an analysis led to an in-depth understanding of the historical causes of the current definitional debate and of the overall context in which it arose.

In the second phase, the archival data used to analyze the historical development of social entrepreneurship was complemented with additional archives and 69 interviews with different stakeholders present in the sector. Archival data added for this phase was identified again with the help of 
databases and references, using as key-words the names of influential organizations, which affected the definitional debate throughout time. Among the new documentation retrieved were organizational websites, books, reports and guides on social entrepreneurship produced by sector intermediaries, newspaper articles and academic papers discussing organizations active in England in the social entrepreneurship space, videos and blogs posted online by members and experts of the sector (see Table 1).

Table 1. Archival data breakdown

\begin{tabular}{lll}
\hline Purpose & Type of source & No. \\
\hline History/Phase 1 & Academic papers & 22 \\
& Government and think tank projects & 12 \\
& Newspapers' and magazines' articles & 256 \\
\hline Definitions and & Academic papers & 33 \\
definitional debate/ & Books & 25 \\
Phase 2 & Events videos or video summaries & 41 \\
& Newspapers' and magazines articles & 293 \\
& Sector experts blogs & 392 \\
& Reports and guides on social entrepreneurship & 138 \\
\hline Total & produced in England & \\
\hline
\end{tabular}

The interviews that were conducted, in conjunction with the collection of archival data, were semi-structured and used both to triangulate the information coming from archives and to explore in-depth the four main topics. Questions asked for these purposes revolved around the definition of the terms "social entrepreneurship," "social entrepreneur" and "social enterprise," the prevailing conception of social entrepreneurship in England, the impact of the definitional debate on the sector and the current state of social entrepreneurship in England. Each interview lasted between 25-90 minutes, with most interviews lasting around 45-50 minutes (see Table 2).

Table 2. Interviews breakdown

\begin{tabular}{ll}
\hline Stakeholders & No. \\
\hline Employees of sector intermediaries & 16 \\
Social entrepreneurs/enterprises & 24 \\
Academics & 12 \\
Businesses & 8 \\
Charities & 9 \\
\hline Total & 69 \\
\hline
\end{tabular}

During the second phase of analysis, a first screening was employed to select, within the data available, the parts where information relevant for this 
project was contained, and to divide their content according to the four main topics on which the interviews were focused. Following such screening, the remaining material was analyzed using an inductive approach (Corley \& Gioia, 2004; Glaser \& Strauss, 1967), which allows us to describe a phenomenon according to the words of participants and to explore concepts not covered by the existing literature (Bryman, 2004). All the data available was scrutinized with the support of NVivo Software ${ }^{\mathrm{TM}}$, searching for themes that emerged "as being important for the description of the phenomenon" (Fereday \& MuirCochrane, 2006, p. 3) through multiple iterations. In the first round of coding, data were divided into sentences or paragraphs discussing a specific topic. In the following iterations, patterns were searched for within and across different topics, according to the Gioia method (Corley \& Gioia, 2004), in order to create and refine overall themes containing all the relevant information for the object of study (definitions of social entrepreneurship and their consequences). A small sample of the codes can be found in Table 3 and 4 .

The final list of codes was combined in the two themes of interest for this paper: the typology of definitions of social entrepreneurship and the explanation of the consequences deriving from the definitional debate. The next session will detail the findings in these two categories.

Table 3. Sample of codes on definitions

\begin{tabular}{|l|l|c|c|}
\cline { 2 - 4 } \multicolumn{1}{c|}{} & $\begin{array}{l}\text { 1ST ORDER CONCEPTS } \\
\text { A social enterprise is a business with a } \\
\text { social or ethical purpose. Its object is to } \\
\text { improve the world we live in through } \\
\text { commercial and sustainable means. }\end{array}$ & $\begin{array}{c}\text { AGGREGATE } \\
\text { DIMENSIONS }\end{array}$ \\
\hline \begin{tabular}{l|l} 
So I think social enterprises are \\
predominantly focussed on a social \\
and/or environmental goal rather than \\
a financial goal, however, I do think of \\
course they have a financial mechanism \\
to sustain themselves which is to earn \\
an income through trading, selling \\
goods or services
\end{tabular} & $\begin{array}{c}\text { Sustainable } \\
\text { business }\end{array}$ & \multirow{2}{*}{ BUSINESSES } \\
\hline $\begin{array}{l}\text { Social enterprise is a business that's } \\
\text { trading for a social purpose, where its } \\
\text { primary purpose is the social one. And } \\
\text { it reinvests the majority of its profits in } \\
\text { the pursuit of those social objectives. }\end{array}$ & Trading for \\
purpose & \\
\hline
\end{tabular}

Social Entrepreneurship and Social Enterprise Phenomenon: Antecedents, Processes, Impact across Cultures and Contexts Marzena Starnawska and Agnieszka Brzozowska (Eds.) 


\begin{tabular}{|c|c|c|c|}
\hline 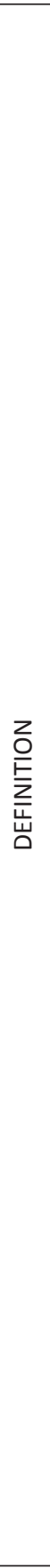 & \begin{tabular}{|l|} 
Technically, social enterprises should \\
be trade-focused, they should operate \\
a triple bottom-line policy, they should \\
have an asset lot where profits might be \\
distributed. \\
I think about it more in terms of taking \\
a more business-like approach to the \\
business of creating social change and \\
trying to create and run models that \\
are... more financially independent. \\
Social entrepreneurship is identifying \\
a problem, a social problem, and \\
choosing to use a business model to fix \\
it, or to start to fix it \\
So I would say the definition is broad \\
for me, it's about a sense of a purpose, \\
which is all about the social impact, \\
but with underlying the strength of a \\
business model, allowing people to \\
make a profit in that kind of context. \\
So for me, a social enterprise is a \\
business with a good cause. It's pretty \\
simple. A social entrepreneur is a \\
person who uses business strategies to \\
achieve social impact. Yeah that's how I \\
define it. It's really simple. \\
Social entrepreneurs are not happy until \\
their ideas have changed the whole \\
society \\
But I think the notion of social \\
entrepreneurship embodies disruption, \\
systems change, making money work, \\
but really looking at really big problems \\
and how do we do this differently \\
So social entrepreneurship is, to me, \\
it's making a change in society when \\
the primary motivator for you is not the \\
financial returns. \\
They've chosen to dedicate their \\
professional lives and much of their \\
personal energy, to solving problems \\
that they have first-hand experience of \\
I think it's just about saying that \\
thinking about new ways of going \\
about business, regardless whether its \\
for-profit or not-for-profit, that makes \\
social change and social impact kind of \\
possible
\end{tabular} & $\begin{array}{l}\text { Business model to } \\
\text { solve social causes }\end{array}$ & BUSINESSES \\
\hline
\end{tabular}




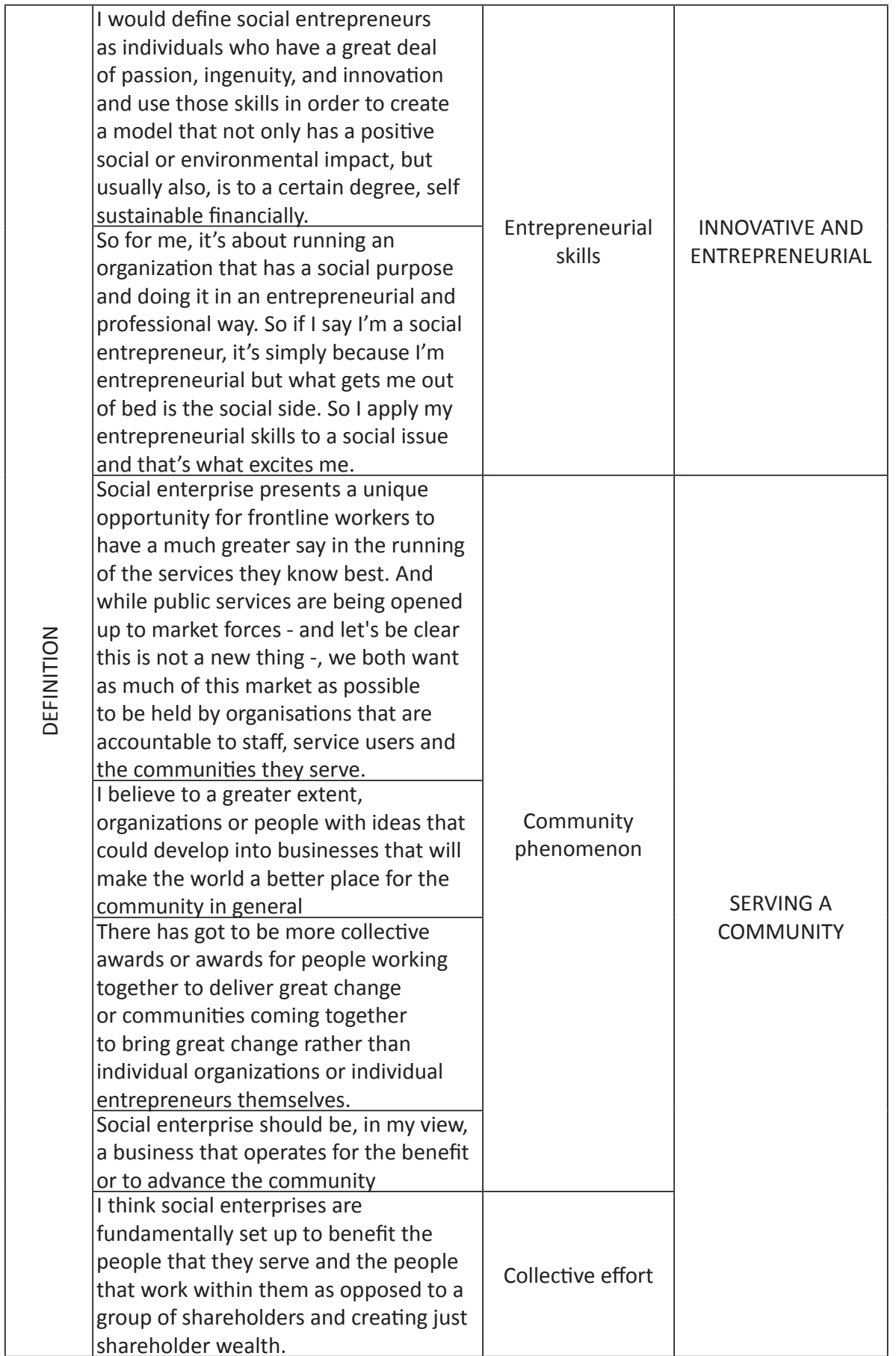


Table 4. Sample of codes on consequences

\begin{tabular}{|c|c|c|c|}
\hline & 1ST ORDER CONCEPTS & \begin{tabular}{|c|} 
2ND ORDER \\
THEMES
\end{tabular} & \begin{tabular}{|c|} 
AGGREGATE \\
DIMENSIONS \\
\end{tabular} \\
\hline \multirow[t]{2}{*}{ 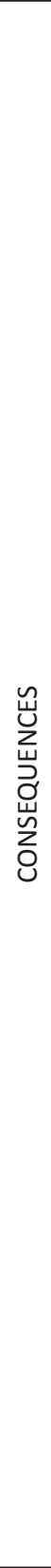 } & $\begin{array}{l}\text { Lots of bright people all coming in it with different } \\
\text { definitions of the same thing isn't helping the sector } \\
\text { right now. It's almost like the sector needs to get } \\
\text { together to make some decisions collaboratively and } \\
\text { announce its intentions publicly } \\
\text { I do think they hamper the sector. I think they prevent } \\
\text { any cross-learning, any cross-collaboration because } \\
\text { they are different animals } \\
\text { It's a very practical problem because of access to } \\
\text { funding. And it's difficult to see how you can resolve } \\
\text { the problem, but it does mean there's an awful lof the } \\
\text { standard funding routes aren't terribly available to } \\
\text { social enterprises } \\
\text { See, the problem is, when the funding stream was } \\
\text { changed back in 2009, 2010 whenever it was, to } \\
\text { support social enterprise activity, all organizations } \\
\text { that relied on funding and grant suddenly changed } \\
\text { the name of their from Fred Blogs whatever to Fred } \\
\text { Blogs Social Enterprise. So you've got hundreds if not } \\
\text { thousands of organizations that are desperately just } \\
\text { spending probably } 80 \% \text { of their week trying to attract } \\
\text { funding which only leaves } 20 \% \text { of their week to do } \\
\text { anything social } \\
\text { All these different definitions just confuse people } \\
\text { I think the problem is, in the public mind, when you } \\
\text { say to them what is a social enterprise, sometimes it } \\
\text { is a little bit fuzzy } \\
\text { If we can achieve a rigorous definition, then those } \\
\text { who support social entrepreneurship can focus their } \\
\text { resources on building and strengthening a concrete and } \\
\text { identifiable field. Absent that discipline, proponents } \\
\text { of social entrepreneurship run the risk of giving the } \\
\text { skeptics an ever-expanding target to shoot at }\end{array}$ & $\begin{array}{l}\text { Confusion } \\
\text { for the } \\
\text { public }\end{array}$ & PROBLEM \\
\hline & $\begin{array}{l}\text { I think anyone who actually wants to get involved or } \\
\text { back schemes, decides what they are interested in } \\
\text { and support that.... The nice thing is that probably } \\
\text { both sides get some attention and actually that gets } \\
\text { people thinking what they think, which might be a } \\
\text { good way to progress } \\
\text { I think we're very focused on having quite clear } \\
\text { boundaries of we think is involving but within that } \\
\text { having a pretty broad territory that covers a lot of } \\
\text { ground and that's important too because we want to } \\
\text { be inclusive and encouraging because that's what the } \\
\text { sector is about }\end{array}$ & Inclusiveness & STRENGTH \\
\hline
\end{tabular}




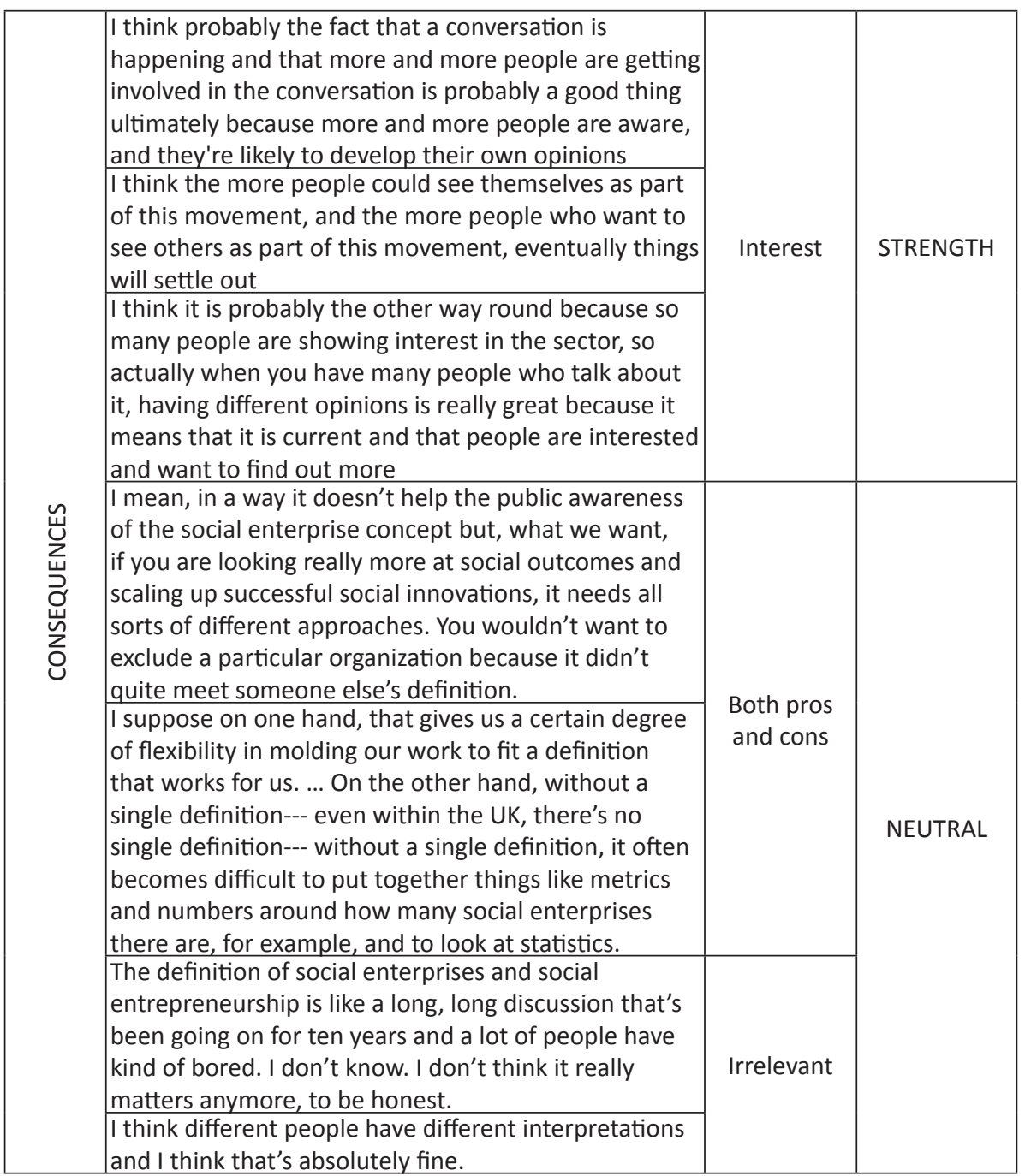

\section{FINDINGS}

\section{Three schools of thought in practice}

Multiple sources of archival data presented evidence of a definitional debate developing within the social entrepreneurship sector in England throughout the last 15-20 years (Ainsworth, 2008; Barrett, 2008; Brown, 2008; Harding, 2004; McCurry, 2005; Plummer, 2005; Seanor \& Meaton, 2007; Simms, 2008). In those documents, in the ones produced by sector stakeholders and in the interviews conducted for this study, it was possible to discern three 
macro-conceptions of social entrepreneurship. The first one refers to social enterprises as businesses, the second one focuses on social entrepreneurs as innovators and the third one considers social entrepreneurship (social entrepreneurs, social enterprises and social entrepreneurial projects) as a community-related phenomenon.

Manager of social enterprise 1: "I mean previous to this, I've been in the social enterprise sector pretty much since the social enterprise term was coined, in fact, I have. And it took me probably seven years to realize that when the School for Social Entrepreneurs was talking about social entrepreneurs, they weren't talking about social enterprise. They were talking about three different types of business model: one is a completely unsustainable business that gets grants, number two is a social enterprise which should be generating its own income, but has a social mission, and then the third one is about an individual entrepreneur who's set up to do basically the same as any other business but happens to be doing something social."

These three macro-conceptions sometimes have an overlap, but more often than not they diverge on the core characteristics they attribute to social entrepreneurship. As a consequence, they have often created open tensions between their proponents. An example of this is the case of UnLtd, whose founding members gradually left it due to disagreement among themselves and with the foundation's CEO, regarding whom to support as social entrepreneur or enterprise with the funds available (Burne James, 2014; Grenier, 2008; interview of UnLtd founder, 2015).

The first macro-conception of social entrepreneurship revolves around social enterprises, described as businesses trading for a social purpose (examples of definitions in Table 3).

Social Enterprise UK website: "Social enterprises are businesses trading for social and environmental purposes. Rather than maximizing private profit, their main aim is to generate profit to further their social and environmental goals."

It is a view supported by the government, by influential sector intermediaries like Social Enterprise UK, the Social Enterprise Mark and Co-ops UK and by the most renowned social enterprises based in England, such as the Big Issue, Divine Chocolate, Belu Water, Hackney Community Transport Group (HCT) or Greenwich Leisure Limited (GLL). Thanks to the support of these visible and powerful players, this conception appeared from the archival data as the most popular one in the public discourse around 
social entrepreneurship in England at present. This was well reflected in the frequency with which it came up in the interviews conducted.

However, possibly because of its success and of the presence among its proponents of organizations owing their survival to the vagueness of the concept (Huckfield, 2014), it is also the conception of social entrepreneurship for which there is a strong internal debate.

Liverpool Post, 7th June 2012: "Of course, at Social Enterprise Network we have a very clear idea of what defines social enterprise and we are working very hard to challenge misconceptions and misrepresentation of the term. ... Debate will naturally remain...but perhaps JM Keynes got it right when he said: "It is better to be vaguely right than precisely wrong."

For example, some people and organizations argue that social enterprises - being businesses - should be financially sustainable and reinvest the majority of their profits to create social impact. Others believe that the core trait of social entrepreneurial business is its shared ownership and not the creation and/or reinvestment of profits. Also, the exact level of revenues that a social enterprise should derive from trade has been open to debate. For example, the Social Enterprise Mark requires organizations to obtain at least $50 \%$ of their revenues from trade to certify them as social enterprises, whereas for the government the threshold is set at $25 \%$ and for Social Enterprise UK a specific threshold around $50 \%$ would be desirable but not needed (Ainsworth, 2010; Cabinet Office, 2012; Findlay, 2013; Jolly, 2012; Ridley-Duff \& Southcombe, 2012; Social Enterprise Mark, 2009; Social Enterprise UK, 2013; Third Sector Magazine, 2013). Other examples of slight variations of the conception of social enterprises as businesses can be found in the quotes below.

Director Magazine, February 2004: "Where social enterprises differ from the traditional model of charity is in tackling the underlying causes of social problems as well as the effects."

Third Sector Magazine, 30th July 2008: "The first model describes enterprises that trade purely to make a financial return but use profits for a social purpose. ... Model two covers enterprises whose trading activity has a social impact, but where a balance is struck between increasing social impact and maintaining a financial return. ... The third model describes businesses whose financial return increases in parallel with their social return. Examples would be farmers markets and wind farms." 
Manager of social enterprise 2: "Social enterprises are asset-locked businesses trading for a social purpose. Sustainable businesses reinvesting their profits into furthering their social mission. Business solutions to social problems. Social entrepreneurs are capitalizing on market failure or business solutions to create social equality."

The second macro-conception focuses instead on social entrepreneurs. It depicts them as innovators and disruptors changing the status quo of multiple sectors to create a fair and equal society (examples of definitions in Table 3). The leading proponents of this view are international organizations like Ashoka, the Schwab Foundation and the Skoll Foundation, some scholars, and multinational corporations such as Unilever.

Ashoka's webpage: "Social entrepreneurs are individuals with innovative solutions to society's most pressing social problems. They are ambitious and persistent, tackling major social issues and offering new ideas for wide-scale change."

Social entrepreneur 1: "So social entrepreneurship is, to me, it's making a change in society when the primary motivator for you is not the financial returns. It's seeing the society change and improve."

Because of its international origins, this macro-conception of social entrepreneurship is not shared by many local and national sector members. Nonetheless, it obtains a significant resonance thanks to the sustained publishing activity of some of its supporters, such as Ashoka or the Skoll Centre (Drayton, 2006; Elkington \& Hartigan, 2008), and to an agreement among its proponents that is stronger than that among those of the other two macroconceptions. Indeed, only in two cases was it possible to observe among the archival documents a slight variation of this macro-conception, due to the inclusion of references to trade and business models in its definition (Garet, 2014; Villa, 2016), and in no case were there traces of a strong internal debate within the supporters of this view.

Finally, the third macro-conception describes social entrepreneurship as the realization of initiatives - either business-like or charity-like - that benefit the community where they are implemented (examples of quotes in Table 3). This view is supported by intermediaries such as the School for Social Entrepreneurs and UnLtd and by some charities such as the Young Foundation, and it was the most prominent conception of social entrepreneurship at the origins of the sector (Grenier, 2008; Huckfield, 2014; Leadbeater, 1997; Teasdale, 2012). 
The causes for its gradual marginalization within the public discourse might be found in the shift of the government's and main funders' priorities from community revitalization to financial sustainability, and in the excessive vagueness of its definition. Indeed, social entrepreneurs included in this view are individuals setting up a social enterprise, any worker/employee/ volunteer participating in the social economy, innovative public servants and society's change-makers (Downer, 2006; Jones \& Keogh, 2006). Similarly, social enterprises that match its focus are cooperatives, social enterprises reinvesting profits and doing projects in their local area, and no-profits creating new employment or inclusion opportunities for marginalized groups (Brodie, 2010; Burne James, 2014; Reid \& Griffith, 2006; Ridley-Duff \& Southcombe, 2012).

Third Sector, 15th June 2010: "Guinness is launching a social entrepreneurship programme in the UK with social enterprise charity UnLtd and young people's charity Rathbone ... for people who develop urban regeneration concepts that will make a positive difference to their local communities."

Manager of social enterprise 3: "I think social enterprises are fundamentally set up to benefit the people that they serve and the people that work within them as opposed to a group of shareholders and creating just shareholder wealth. It is about taking the perspective of the community versus the perspective of only patients' care."

Altogether, the three macro-conceptions of social entrepreneurship have created a definitional debate. Some of the sector members coming from the charity world have disagreed vehemently with the risk-taking attitude implicit in the conception of social entrepreneurs as innovators and disruptors (Cater, 2006; Little \& Warrell, 2007; Palmer, 2006). Individuals and organizations connected to the cooperative tradition have instead worried about the focus of the same macro-view on "hero-preneurs," discounting the collective effort required for social change and the history of social entrepreneurship as a phenomenon meant to foster social inclusion (Dey \& Teasdale, 2016). On the other hand, proponents of the "social entrepreneurs as innovators" view have often criticised the focus on "social enterprises as businesses" or on "social entrepreneurs as community-regenerators" because these types of actors lack novelty and the ambition of changing the root causes of the problems they are tackling (Caulkin, 2006). 
Academic 1: "You know, the biggest threat for me is that the social enterprise sector becomes a quasi-government sub-contracting group that are delivering goods and services but that are not changing the actual problem and for me the key of entrepreneurship is ... about really promoting system change."

Social entrepreneur 2: "There is a huge emphasis on the sort of the personality cult and I think that, actually, isn't always that helpful. ... actually, you know, the world is made by lots of people who apply their time and energy, skills and not just the few in the limelight who happen to be the people who set up things and managed to take them forward."

The definitional debate has been a constant feature of the sector and, as such, can be expected to have shaped its development. The next section will explore if and how this was the case, by looking at what sector members consider to be the current characteristics of the sector that can be attributed to the definitional debate.

\section{The consequences of the definitional debate}

While almost everyone agrees on the presence of a definitional debate around the concept of social entrepreneurship, there are very different opinions on what this means for the sector. According to some people and organizations, the lack of a single definition is a problem, for others it is an opportunity. Finally, a third group sees the definitional debate as something of interest only for academics. In general, those that were more critical about the definitional debate were the managers of social enterprises and the sector intermediaries connected to either the first or the third macro-conception. On the contrary, businesses and scholars were generally discounting the definitional debate as something belonging to the past. Interestingly, most of the views in support of the definitional debate came from the proponents of the second macro-view. This might be explained by the fact that, being part of a sub-sector which is much more homogeneous in its interpretation of social entrepreneurship, they are less subject to the contradictions and issues that might arise out of the lack of a clear definition.

Sector members seeing the definitional debate as negative justify their critiques with five core points. Firstly, the lack of a single definition hampers the effective provision of funds to social entrepreneurs and enterprises. Secondly, it makes it impossible for the government to grant the sector statutory rights and tax advantages. Thirdly, it hampers the growth of public awareness about the uniqueness and value of this new sector. Fourthly, it 
does not allow all sector stakeholders to push together for the growth and development of the sector. Finally, it reduces the probability of doing an accurate mapping of the social entrepreneurial activity present in the country. These problems have been characterizing the sector since its inception and are still felt nowadays and some sector members believe that the definitional debate played a role in this sense.

As far as funding is concerned, the lack of a univocal definition of social enterprises and entrepreneurs contributes to the disconnection between the social entrepreneurship sector and the social investment one (Cabinet Office, 2012; Nicholls, 2006; Pharoah, 2012; Schwartz, 2012; Temple, 2014; Third Sector Magazine, 2015; Villa, 2016). Funders are often unable to distinguish social enterprises from traditional businesses or charities and, therefore, are less willing to invest in them (Baines, Bull \& Woolrych, 2010; Chapman, Forbes \& Brown, 2007; Jones \& Keogh, 2006). At the same time, the lack of clarity around the concept opens up the possibility for any organization or individual to label herself as "social enterprise" or "social entrepreneur" and thus to access special funds, investments and grants that were created to support the sector (Simms, 2008).

Employee of sector intermediary 1: "(The lack of a clear definition) is a very practical problem because of access to funding. ...it does mean there's an awful lot of the standard funding routes that aren't terribly available to social enterprises. And some of the issues that relate to that ...like including social enterprises in supply chains and allowing social enterprises to bid for government funding contracts, don't work terribly well because for a lot of the social enterprises."

Third Sector, 4th June 2013: "The purists tend to see social investment as something that should be dedicated to encouraging a particular type of highly social organization. There is not yet a uniform view on exactly what type of organization ought to be supported, but purists...believe businesses that are not so purely focused ought to receive less or no support, because they are not really social enterprises."

Legislation-wise, the lack of a definition prevents the creation of tax breaks and statutory rights because the government cannot isolate and establish who will benefit from them. Additionally, it reduces the impact of policy reforms like the Social Value Act - an act meant to favor the entrance of third-sector organizations in the supply chains of the public sector. In fact, 
public bodies and local authorities cannot easily distinguish social enterprises from other types of organizations that bid for public contracts.

Academic 2: "The lack of clarity has meant that there haven't been tax benefits, or tax breaks or funding programs because they can't decide who would get it and who wouldn't."

Third Sector, 1st October 2013: "O'Donohoe also called for a clear definition of social enterprise 'We're asking big businesses and government bodies to involve social enterprises in their supply chains, ' he said. "We can't ask them to do a social audit every time."

The presence of multiple definitions of social entrepreneurship also contributes to the persistent low awareness among the general public about the sector and its specificities (Chapman et al., 2007; Donovan, 2009; Grewal, 2008; Morrison, 2013; Muñoz, 2009; Richardson, 2016). Indeed, the lack of a definition makes it difficult to explain to people what exactly is distinctive about social entrepreneurs and enterprises. In turn, this can mean that social enterprises and entrepreneurs often risk spending more time proving to funders and customers their value rather than actually producing social impact.

Employee of sector intermediary 2: "(Approaching corporate partners) is a challenge, for sure. For sure, it is a challenge and it always does take a little bit of explaining and even then, it's often really when they meet a social entrepreneur, that ... they're like: I get it. I get what you mean."

Third Sector magazine, 13th October 2009: "The standard of knowledge among ordinary people who don't work in the sector is very low, 'she says. 'Social enterprise just isn't in the public domain. It's not an easy concept for many people to grasp, especially that it's not 'not-for-profit' but 'not-forpersonal-profit'.' Many people, she says, think of social enterprise as a public sector activity."

Independent.co.uk, 14th July 2013: "There's clearly an appetite in the market for social enterprise products; people look at what we do and their faces light up," she said. "But when we say it's a social enterprise, they don't really understand it. We talk [instead] about balancing business and social needs. They are both equally important." 
Fourthly, according to some interviews (but not to archival data, where this view could not be traced) the lack of a definition does not allow the sector to push as a whole for the obtainment of more resources and attention, generating instead an increasing numbers of buzzwords. This might end up lowering its legitimacy with external stakeholders, such as the national and local authorities or corporates and businesses.

Employee of sector intermediary 3: "I think the onus is on the sector itself to demonstrate a united front, to be clear on these things and not to have internal debates that detract from the issues because actually most people's definitions have a lot more in common than they do differences. But it is a risk. I think at the moment, it's not a damaging one but ...if it starts to become fragmented, you lose the power of the whole and that's a risk as well." Manager of social enterprise 4: "I think it's important to clearly define what a social enterprise is because if it becomes fuzzy or becomes nebulous, then it affects policy and opinion-making - for example we work with the local enterprise partnership and if we all start falling out about the definitions, what it is and what it's not, they won't take us seriously."

Finally, some of the interviewees were worried about the definitional debate because it hampers their attempts to map the presence of social enterprises country-wise or in specific local areas. This can mean missed opportunities for interested people and organizations to get in touch with social entrepreneurs and enterprises and for the latter to know where supporters and resources are located. Additionally, this prevents the production of sound statistics about the actual growth of the sector.

According to many interviewees and to some archival data, however, maintaining multiple definition of social entrepreneurship is mostly beneficial (Dearden-Phillips, 2011; Ridley-Duff \& Southcombe, 2012; Schwartz, 2013). First of all, it makes the sector inclusive and, consequently, favors its growth and hype. The more people and organizations consider themselves as involved in the sector, the more "word of mouth" is generated about it.

Member of charity 1: "I think probably the fact that a conversation is happening and that more and more people are getting involved in the conversation is probably a good thing ultimately because more and more people are aware, and they're likely to develop their own opinions."

Employee of sector intermediary 4: "I think it is really good that the debate continues because I think the debate is the next generation learning about 
these issues and textures and so I think it is really healthy that that debate is vibrant, I am not the slightest a bit bored about it."

Secondly, by keeping sector boundaries as broad as possible opens up opportunities for organizations with very different conceptions of social entrepreneurship to get involved in it, and to find their own niche. This, in turn, is positive because it facilitates the attraction of new players and it ensures that different types of social entrepreneurial activities can find the support they need.

Social entrepreneur 3: "I think anyone who actually wants to get involved or back schemes, decides what they are interested in and support that...The nice thing is that probably both sides get some attention and actually that gets people thinking what they think, which might be a good way to progress."

Social entrepreneur 4: "I think you do have to support individuals ...but, you know, there is only so much support that anybody could individually give me, before I actually need the way Liverpool and Manchester councils operate to begin to change also."

Finally, some interviewees felt that the sector is still young and thus it is normal for it to have unclear boundaries and definitions. Its openness creates room for innovation and for making people feel part of a big community.

Member of charity 2: "It's creating a bit of a community that people can feel a part of.... remember making a presentation and people came up from the audience afterwards and said, "Thank you for giving me a label for what I am. I know that I can make money and I know that I can do good and I didn't know that there were other people who thought this way"

Besides people and organizations feeling strongly negative or positive about the definitional debate, there are also some sector members who are neutral about it. Their main argument is that in general there is a broad agreement, so small differences don't matter and merely serve to create distractions. Rather, what matters is to support people and organizations, who are trying to create a better world and make a positive change.

Social entrepreneur 5: "I think it's a distraction from what really matters. People should be---organizations should be judged by their impact, not about whether they're profit-making or not. Organizations should be judged by how effectively they're run and by the company culture that they're able to create. 
... Those are the things that we should be talking about and shining light on good examples. I think this whole hype around social enterprises has created a lot of distraction, has created a lot of new buzz words, it has created sort of new sectors around -it's something that really nobody is quite sure how to define and that really has always existed."

In some cases, the interviewees holding this opinion recognized the existence of both benefits and issues generated by the definitional debate but believed that, overall, their trade-off and leveling out of each other made the whole disquisition irrelevant.

Business 1: "It's a difficult question. I think the debate about defining what a social enterprise is, has become pretty stale, and it's not something that people are really talking about anymore. ...l think in the end, no one is probably going to agree on one single definition of it. I suppose on one hand that gives us a certain degree of flexibility in moulding our work to fit a definition that works for us. ... On the other hand, without a single definition--- even within the UK, there's no single definition--- without a single definition, it often becomes difficult to put together things like metrics and numbers around how many social enterprises there are, for example, and to look at statistics."

In some other cases, interviewees felt that the sector was so inclusive at this point and its boundaries so ill-defined that the chance to reach an agreement is lost forever and should, therefore, be excluded from the public discourse in favor of topics for which something could still be done.

Social entrepreneur 5: "I don't know. The definition of social enterprises and social entrepreneurship is like a long, long discussion that's been going on for ten years and a lot of people have kind of bored. I don't know. I don't think it really matters anymore, to be honest. ... I just think it's worthless because nobody really understands what it means and because it's become so wide, it doesn't really mean anything anymore.

In conclusion, the data showed the presence of three different conceptions of social entrepreneurship within the sector in England. Most of the archival data consulted and the interviews conducted showed a widespread awareness among sector members of their different conceptions of the sector, of its role and of its boundaries. However, whilst most people agreed on the lack of a single definition, it was hard to understand what its consequences are. In 
fact, views on the matter varied from positive, to negative, to neutral. The next section discusses how these findings relate to the existing literature.

\section{DISCUSSION}

The three views of social entrepreneurship that could be traced in the data partially match those of the three schools of thought identified by the existing literature. The "social entrepreneurs as innovators" view is closely related to the school of thought referred to by Defourny and Nyssens (2010) as "The Social Innovation School of Thought" (p. 41) and to the academic discourse that Mair and Marti (2006) described as focused on the catalysts for social transformation. The "social enterprises as businesses" view is instead connected to the "EMES approach to social enterprise" (Defourny \& Nyssens, 2010, p.42) and, to a certain extent, to the scholarship looking at social practices of businesses (Mair \& Martí, 2006). Finally, the view of "social entrepreneurship as community initiatives" can be seen as implicitly encompassing the definitions of social entrepreneurship as a collective activity, solving failures of either the public or private sectors (Bacq \& Janssen, 2011). Additionally, both the business-related and the communityrelated views sometimes include the "Earned Income" school of thought (Defourny \& Nyssens, 2010, p.40; Sepulveda, 2015), by accepting within their realm charities interested in becoming financially self-sustainable or no-profits engaging in revenue-generating activities for the benefit of their communities.

The data collected for this study also confirms the findings of Nicholls (2010) and Teasdale (2012) regarding the presence in the sector of paradigm-building actors fighting for legitimacy in the space and proposing diverging views of social entrepreneurship and social enterprises. Several interviewees, when commenting on the definitional debate, mentioned sector intermediaries, financial intermediaries and umbrella bodies as one of the causes of the presence of multiple definitions of social entrepreneurship. They believed that the insistence of certain players on different nuances of the definition, in order to support their own work in the sector, made it difficult to reach an official definition even if a broad agreement was already in place. Finally, some of the considerations about the negative consequences of the lack of a clear definition, such as the opportunity for any organization to label itself as a social enterprise, supported the findings of Dey and Teasdale (2016) on organizations sometimes only pretending to be social enterprises in order to obtain resources. 
However, there are also differences between the academic debate on social entrepreneurship and the one happening in the sector in England. On the one hand, the scholarly discourse rarely focuses explicitly on social entrepreneurship as a community-related activity. This might suggest that such a definition is probably typical of the sector in England and might not be sufficiently represented in other contexts. On the other hand, the conception of "social entrepreneurship as engagement of no-profits in revenuegenerating activities", often cited by the literature (Bacq \& Janssen, 2011; Defourny \& Nyssens, 2010; Hoogendoorn et al., 2010; Mair \& Martí, 2006), was not really traceable in the data, if not within a few quotes that could be connected to either the business- or community-related macro-conceptions..

This finding conflicts with those of Teasdale (2012), which presented the "Earned income" school of thought as the one towards which the sector in England had been heading since 2006. Furthermore, while Teasdale (2012) placed cooperatives as a stand-alone conceptualization of social enterprise present in England, according to the data gathered for this study, cooperatives are often included in the "social enterprise as business" discourse or in the "social entrepreneurship as community-related phenomenon" and only appeared as a stand-alone category in some historical archives. These incongruences might be explained by the different sample and sector boundaries used by the two studies (social enterprises and paradigm-builders conceptions for Teasdale (2012) vs. social entrepreneurship and generalstakeholders conceptions for this paper), or by a further change of the public discourse since 2010, the year in which Teasdale's data collection stopped.

The evolution of the definitional debate and of the public discourse observed in the archival data also suggests a trend that the existing literature on the sector still has not addressed: the increasing shift of the sector in England towards the entrepreneurial and business side of social entrepreneurship, with no-profits and community-related initiatives being gradually left out of the public discourse. This trend can be attributed to a mix of changes at the macro-level - such as the economic crisis - and at the policy level - such as the institution of the social investment sector and the encouragement of self-sustainable social enterprises able to deliver public services (Dey \& Teasdale, 2016; Hazenberg et al., 2016; Nicholls \& Teasdale, 2016; Sepulveda, 2015; Teasdale, 2012). As such, it confirms the model elaborated by Kerlin (2013), which included the type of government and its political orientation, and macro-factors such as economic development, in the institutional conditions shaping the evolution of social entrepreneurship in different countries.

The core contribution of this paper, however, comes from the findings on the consequences of the presence of a definitional debate in the social 
entrepreneurship sector. Thus far, the lack of clarity around the meaning of social entrepreneurship has prevalently been portrayed as a negative issue. From an academic point of view, the impossibility to define a concept, hampers the creation of a dedicated scholarly field, neatly separated from existing ones such as entrepreneurship and the development of a clear research agenda (Austin, 2006; Lehner \& Kansikas, 2013; Mair \& Martí, 2006; Nicholls, 2010). On the contrary, for the stakeholders involved in the social entrepreneurship sector, the lack of a univocal definition of the phenomenon is not perceived as necessarily a problem. The findings showed that in England, members of the sector consider the lack of a definition sometimes as an issue, sometimes as an opportunity, and sometimes as something that does not matter.

The reasons why the definitional debate might be an issue complement and partially disconfirm the hypotheses of Peredo and McLean (2006). The two authors mentioned three potential, practical downsides of the lack of a definition: the absence of sector-specific performance metrics and evaluation standards; the missed opportunity of creating legislative support; and the difficulty in attracting talent. The findings of this paper confirmed that the legislative support for the sector could be hampered by the lack of a definition. However, neither interviews nor archival data mentioned the sourcing of talent as a problem and even if the absence of performance metrics often appeared in the archival data as an issue, it was never connected as such to the definitional debate. At the same time, the findings highlighted a new set of issues that can arise due to the multiplicity of definitions of social entrepreneurship. These issues range from the obtainment of appropriate financial and non-financial support for social entrepreneurs and enterprises, to the difficulties in mapping the sector and in raising awareness of it among the general public or in lobbying for it with a single voice.

\section{CONCLUSION}

The paper set out to enquire what the consequences of a lack of definition of social entrepreneurship are for sector members and stakeholders. To do so, it looked at data from the social entrepreneurship sector in England, where the presence of a definitional debate is well known. The findings show that the meanings attributed by sector members to the concepts of "social entrepreneurs" and "social enterprises" - at least in England - are slightly different from those presented by the academic literature. This might suggest that the practicing of social entrepreneurial activities and the involvement in the sector of multiple paradigm-building players are changing the focus of 
this emerging sector over time, or that the scholar view of the sector is not fully aligned with its actual development.

The findings also show that the lack of a single conception of social entrepreneurship has negative consequences, not only for the study of this discipline, as extensively discussed by the literature, but because it can also cause issues for practitioners. However, this might not be necessarily the case. Some sector members, indeed, consider the definitional debate as a strength of the sector, and not just as a liability. Accepting multiple views makes the sector inclusive, open to innovation, and supportive of a wide variety of projects that aim to benefit society at large. The fact that the sector has kept on growing in England over the past 20 years might mean that these benefits actually overcome, or at least match, the negative consequences of the definitional debate. As such, the latter might also be seen as irrelevant for the sector and its stakeholders

The study presents some limitations. Firstly, it is based on a single case study; consequently, its findings cannot be generalized and may be specific to the sector analyzed. Secondly, it relies on interviews and archives, which risk offering only a partial view of what happens in the sector and which have intrinsic biases, for example, their production based on a specific goal or input. Finally, the relatively limited number of interviews makes it hard to establish how widespread and detrimental the issues and benefits of the definitional debate emerging from the findings are.

Nonetheless, the presence of these limitations, together with the novelty of some of the findings, also opens up several avenues for future research. The only partial alignment between the schools of thought on social entrepreneurship described in the academic literature and those that emerged from the data on the English social entrepreneurship sector, calls for more empirical studies on how the terms "social entrepreneurship", "social enterprises" and "social entrepreneurs" are used in practice. Additionally, it calls for a revision and update of the academic discourse on social entrepreneurship.

Furthermore, it would be essential to explore further the state of the sector in England with a quantitative study, verifying the findings of this paper with a bigger sample of stakeholders. Finally, it would be interesting to analyze in greater depth, maybe with the use of a comparative study, the nature of institutional conditions and organizational strategies that give rise, and persistence, to the definitional debate around social entrepreneurship. 


\section{References}

Achleitner, A.-K., Spiess-Knafl, W., Lutz, E., \& Mayer, J. (2012). Disentangling gut feeling: Assessing the integrity of social entrepreneurs. VOLUNTAS: International Journal of Voluntary and Nonprofit Organizations, 24(1), 93-124.

Ainsworth, D. (2008, December 10). Social enterprise hallmark goes national. Third Sector, p. 11.

Ainsworth, D. (2010, May 18). Steady rise for enterprise mark. Third Sector, p. 2. Alcock, P. (2010). Building the Big Society : A new policy environment for the third sector in England. The Policy Press, 1(3), 379-389.

Alter, K. (2007). Social Enterprise Typology. Washington, DC.: Virtue Ventures LLC. Ashoka UK. (2015). Ashoka in the UK 2015. Retrievied from https://www. ashoka.org/en/country/united-kingdom-0

Austin, J.E. (2006). Three Avenues for social entrepreneurship research. In J. Mair, J. Robinson \& K. Hockerts (Eds.), Social Entrepreneurship (pp. 2233), Basingstoke: Palgrave Macmillan.

Austin, J.E., Stevenson, H., \& Wei-Skillern, J. (2006). Social and commercial entrepreneurship: Same, different, or both? Entrepreneurship Theory and Practice, 30(1), 1-22.

Bacq, S., \& Janssen, F. (2011). The multiple faces of social entrepreneurship: A review of definitional issues based on geographical and thematic criteria. Entrepreneurship \& Regional Development, 23(5-6), 373-403.

Baines, S., Bull, M., \& Woolrych, R. (2010). A more entrepreneurial mindset? Engaging third sector suppliers to the NHS. Social Enterprise Journal, 6(1), 49-58.

Barley, S.R., \& Tolbert, P.S. (1997). Institutionalization and structuration: Studying the links between action and institution. Organization Studies, 18(1), 93-117.

Barrett, H. (2008, July 30). Enterprise special: Three that thrive. Third Sector, p. 18.

Benjamin, A. (2004, October 9). Skoll backs social business school. The Guardian Special Supplement, p. 17.

Borzaga, C., \& Defourny, J. (Eds.). (2001). The Emergence of Social Enterprise. London: Routledge.

Brodie, D. (2010, December 15). Talks over role of social enterprise. East Anglian Daily Times, p. BIZZ.

Brown, J. (2008, August). Letter of the month. Director, 27.

Bryman, A. (2004). Social Research Methods ( $2^{\text {nd }}$ ed.) Oxford: Oxford University Press.

Burne James, S. (2014, October 24). Two social enterprises refuse further funds from UnLtd over "erosion of not-for-private-profit principles." Third Sector.

Cabinet Office. (2012). Social Enterprise: Market Trends. London.

Cater, N. (2006, November 15). Skollarship, or how to forget your scruples. Third Sector. 
Caulkin, S. (2006, February 12). How the not-for-profit sector became big business. The Observer, p. 8.

Chapman, T., Forbes, D., \& Brown, J. (2007). "They have God on their side": The impact of public sector attitudes on the development of social enterprise. Social Enterprise Journal, 3(1), 78-89.

Choi, N., \& Majumdar, S. (2013). Journal of Business Venturing Social entrepreneurship as an essentially contested concept: Opening a new avenue for systematic future research. Journal of Business Venturing, 29(3), 1-14.

Corley, K.G., \& Gioia, D.A. (2004). Identity, ambiguity and change in the wake of a corporate spin-off. Administrative Science Quarterly, 49(2), 173-208.

Corner, P.D., \& Ho, M. (2010). How Opportunities develop in social entrepreneurship. Entrepreneurship Theory and Practice, 34(4), 635-659.

Dacin, P.A., Dacin, M.T., \& Matear, M. (2010). Social entrepreneurship : Why we don' $\mathrm{t}$ need a new theory and how we move forward from here. Academy of Management Perspectives, 24(3), 37-58.

Dearden-Phillips, C. (2011). Losing my religion? The theology of social enterprise. Retrieved March 15, 2017, from http://nakedentrepreneur. blogspot.it/2011/01/losing-my-religion-theology-of-social.html

Dees, J.G., \& Anderson, B.B. (2006). Framing a theory of social entrepreneurship: Building on two schools of practice and thought. In Research on Social Entrepreneurship: Understanding and Contributing to an Emerging Field (pp. 39-66). Retrievied from https://centers.fuqua. duke.edu/case/wp-content/uploads/sites/7/2015/02/BookChapter_ Dees_FramingTheoryofSE_2006.pdf

Defourny, J., \& Nyssens, M. (2010). Conceptions of social enterprise and social entrepreneurship in Europe and the United States: Convergences and divergences. Journal of Social Entrepreneurship, 1(1), 32-53.

Dey, P., \& Steyaert, C. (2010). The politics of narrating social entrepreneurship. Journal of Enterprising Communities: People and Places in the Global Economy, 4(1), 85-108.

Dey, P., \& Teasdale, S. (2016). The tactical mimicry of social enterprise strategies: Acting "as if" in the everyday life of third sector organizations. Organization, 23(4), 485-504.

Donovan, T. (2009, October 13). Social enterprise needs a profile. Third Sector, p. 13.

Downer, K. (2006, April 19). Social entrepreneurs: Hard heads, high minds. Third Sector, p. 28.

Drayton, B. (2006). The citizen sector transformed. In A. Nicholls (Ed.), Social Entrepreneurship : New Models of Sustainable Social Change (pp. 4555). Oxford: Oxford University Press.

EKOS. (2014). Social Enterprise Mapping Study. Retrievied from https://www. google.pl/url?sa=t\&rct=j\&q=\&esrc=s\&source=web\&cd=1\&cad=rja\&u act $=8 \&$ ved=0ahUKEwjJjK-nmqHaAhXIdCwKHamNDkgQFggsMAA\&url

Social Entrepreneurship and Social Enterprise Phenomenon: Antecedents, Processes, Impact across Cultures and Contexts

Marzena Starnawska and Agnieszka Brzozowska (Eds.) 
=https\%3A\%2F\%2Fhttps://www.biglotteryfund.org.uk/-/media/Files/ Research\%20Documents/er_eval_social_enterprise_mapping_study.pdf Elkington, J., \& Hartigan, P. (2008). The Power of Unreasonable People: How Social Entrepreneurs Create Markets That Change the World. Brighton: Harvard Business School Press.

Fereday, J., \& Muir-Cochrane, E. (2006). Demonstrating rigor using thematic analysis: A hybrid approach of inductive and deductive coding and theme development. International Journal of Qualitative Methods, 5(1), 80-92.

Findlay, L. (2013, August 5). Finding genuine social value. Local Government Chronicle (LGC).

Finn, W. (2004, February). Soul Traders. Director, 58-62.

Fowler, A. (2000). NGDOs as a moment in history: Beyond aid to social entrepreneurship or civic innovation? Third World Quarterly, 21(4), 637-654.

Garet, L. (2014, July 4). Social entrepreneurship: for profit businesses ending hunger and malnutrition. M2 PRESSWIRE.

Garrow, E.E., \& Hasenfeld, Y. (2014). Social enterprises as an embodiment of a neoliberal welfare logic. American Behavioral Scientist, 58(11), 14751493.

Glaser, B.G., \& Strauss, A.L. (1967). The Discovery of Grounded Theory: Strategies for Qualitative Research. Chicago: Aldine Pub.

Grenier, P. (2008). The role and significance of social entrepreneurship in UK social policy. London: London School of Economics.

Grenier, P. (2009). Social entrepreneurship in the UK: From rhetoric to reality? In R. Ziegler (Ed.), An Introduction to Social Entrepreneurship: Voices, Preconditions, Contexts (pp. 174-206). Cheltenham : Edward Elgar.

Grewal, H. K. (2008, October 3). "Few know" about social enterprise. Regeneration \& Renewal, p. 7.

Haigh, N., Walker, J., Bacq, S., \& Kickul, J. (2015). Hybrid organizations: Origins, strategies, impacts and implications. California Management Review, 57(3), 5-12.

Harding, R. (2004). Social enterprise: The new economic engine? Business Strategy Review, 15(4), 39-43.

Hazenberg, R., Bajwa-Patel, M., Roy, M.J., Mazzei, M., \& Baglioni, S. (2016). A comparative overview of social enterprise "ecosystems" in Scotland and England: An evolutionary perspective. International Review of Sociology, 26(2), 205-222.

Hill, T.L., Kothari, T.H., \& Shea, M. (2010). Patterns of meaning in the social entrepreneurship literature: A research platform. Journal of Social Entrepreneurship, 1(February), 5-31.

Hoogendoorn, B., Pennings, E., \& Thurik, R. (2010). What do we know about social entrepreneurship: An analysis of empirical research. report series: research in management. Retrievied from https://repub.eur.nl/ pub/16558/ERS-2009-044-ORG.pdf 
Huberman, M.A., \& Miles, M.B. (2002). The Qualitative Researcher's Companion. Thousand Oaks, [Calif.]: SAGE.

Huckfield, L. (2014). The Rise and Influence of Social Enterprise, Social Investment and Public Service Mutuals (July No. Working Paper 3).

Huybrechts, B., \& Nicholls, A. (2012). Social entrepreneurship: definitions, drivers and challenges. In C.K. Volkmann, K.O. Tokarski \& K.Ernst (Eds.), Social Entrepreneurship and Social Business (pp. 31-48). Germany: Gabler Verlag.

Jolly, R. (2012, June 7). Social enterprise. Liverpool Post, p. 36.

Jones, D., \& Keogh, W. (2006). Social enterprise: A case of terminological ambiguity and complexity. Social Enterprise Journal, 2(1), 11-26.

Kerlin, J. (2013). Defining social enterprise across different contexts. A conceptual framework based on institutional factors. Nonprofit and Voluntary Sector Quarterly, 42(1), 84-108.

Leadbeater, C. (1997). The Rise of the Social Entrepreneur. London: Demos.

Lehner, O.M., \& Kansikas, J. (2013). Pre-paradigmatic status of social entrepreneurship research: A systematic literature review. Journal of Social Entrepreneurship, 4(2), 198-219.

Little, M., \& Warrell, H. (2007, February 7). Is it time to be more enterprising? Third Sector.

Mair, J., \& Martí, I. (2006). Social entrepreneurship research: A source of explanation, prediction, and delight. Journal of World Business, 41(1), 36-44.

Martin, R. L., \& Osberg, S. R. (2007). Social entrepreneurship: The case for definition. Stanford Social Innovation Review.

McCurry, P. (2005, January 19). enterprise culture - where social benefit meets business. Third Sector, p. 26.

Morrison, S. (2013, July 14). Special report: Social entrepreneurship - it's boom time for businesses with heart; They are diverse, dynamic - and doing well in the market. And now social enterprises are to get their own "champion." Independent.co.uk, p..

Muñoz, S. (2009). Social enterprise and public sector voices on procurement. Social Enterprise Journal, 5(1), 69-82.

Nicholls, A. (2006). Introduction. In A. Nicholls (Ed.), Social Entrepreneurship : New Models of Sustainable Social Change (pp. 1-35). Oxford: Oxford University Press.

Nicholls, A. (2010). The legitimacy of social entrepreneurship: Reflexive isomorphism in a pre-paradigmatic field. Entrepreneurship Theory and Practice, 44(0), 611-634.

Palmer, P. (2006, May 10). Social enterprise: new spin, old story. Third Sector, p. 21.

Peredo, A.M., \& McLean, M. (2006). Social entrepreneurship: A critical review of the concept. Journal of World Business, 41, 56-65.

Perrini, F. (2006). Social entrepreneurship domain: Setting boundaries. In F. Perrini (Ed.), The New Social Entrepreneurship: What Awaits Social

Social Entrepreneurship and Social Enterprise Phenomenon: Antecedents, Processes, Impact across Cultures and Contexts

Marzena Starnawska and Agnieszka Brzozowska (Eds.) 
Entrepreneurial Ventures? (pp. 1-25). Cheltenham: Edward Elgar Publishing Limited.

Pharoah, C. (2012, May 1). In my view - Heed the case of Linda Kirk who tried and failed to get local social investment. Third Sector, p. 13.

Plummer, J. (2005, January 12). The next decade: Don't stop now. Third Sector, p. 26.

Reid, K., \& Griffith, J. (2006). Social enterprise mythology: Critiquing some assumptions. Social Enterprise Journal, 2(1), 1-10.

Richardson, M. (2016,). Can social enterprise go truly global?; The Middle East and North Africa is a challenging region for social enterprise. Despite this there are some impressive examples of social enterprise already tackling the multiplicity of problems being faced there. The Guardian, p. Partner zone.

Ridley-Duff, R.J., \& Southcombe, C. (2012). The social enterprise mark: A critical review of its conceptual dimensions. Social Enterprise Journal, 8(3), 178-200.

Schwartz, R. (2012, March 20). Competitions offer social enterprises worthy prizes. Third Sector, p. 19.

Schwartz, R. (2013, June 4). We must get investors onto the ladder of social finance. Third Sector, p. 19.

Seanor, P., \& Meaton, J. (2007). Making sense of social enterprise. Social Enterprise Journal, 3(1), 90-100.

Sen, P. (2007). Ashoka's big idea: Transforming the world through social entrepreneurship. Futures, 39(5), 534-553.

Sepulveda, L. (2015). Social Enterprise - A new phenomenon in the field of economic and social welfare? Social Policy \& Administration, 49(7), $842-861$.

Simms, J. (2008, June). Moral behaviour. Director, 52-55.

Social Enterprise Mark. (2009). Checklist. Retrieved February 6, 2017, from http://www.socialenterprisemark.org.uk/assessment/\#checklist

Social Enterprise UK. (2013). About social enterprises - FAQs. Retrieved May 22, 2017, from https://www.socialenterprise.org.uk/Pages/FAQs/ Category/FAQs

Teasdale, S. (2012). What's in a name? Making sense of social enterprise discourses. Public Policy and Administration, 27(2), 99-119.

Temple, N. (2014, January 21). Social investment should break through this year. Third Sector, p. 19.

Third Sector Magazine. (2013, January 15). Seven days in the sector: SEUK unveils identity badges. Third Sector, p. 6 .

Third Sector Magazine. (2015, July 1). Two friends who woke up and smelled the coffee. Third Sector, p. 62.

UK government. (2015). Social enterprise insights Annex 3 - Partners and key players. Retrieved February 8, 2015, from https://data.gov.uk/data/ contracts-finder-archive/download/1699299/42395221-d0c3-45318736-293a195aa784 
Vasi, I.B. (2009). New heroes, old theories? Toward a sociological perspective on social entrepreneurship. In R. Ziegler (Ed.), An introduction to Social Entrepreneurship: Voices, Preconditions, Contexts (pp. 155-173). Cheltenham, UK : Edward Elgar.

Villa, M. (2016, September 15). Social entrepreneurship, where the glass ceiling is already smashed. The Evening Standard (London), p. 15.

Villeneuve-Smith, F., Temple, N., Brown, B., Gregory, D., \& BMG Research. (2015). State of Social Enterprise Survey 2015.

Warrell, H. (2008, July 30). Social enterprises categorised. Third Sector, p. 3. Young, R. (2004, October 13). The seeds are sown for social entrepreneurs. Third Sector, p. 16.

Zietsma, C., \& Lawrence, T. B. (2010). Institutional work in the transformation of an organizational field: The interplay of boundary work and practice work. Administrative Science Quarterly, 55(2), 189-221.

\begin{abstract}
Abstrakt
Koncepcja przedsiębiorczości społecznej od zawsze była kwestionowana, zarówno $w$ dyskursie akademickim, jak i wśród praktyków. Badacze wkładajq wiele wysiłku $w$ analizę odmiennych definicji przedsiębiorczości społecznej i negatywnego wpływu takiej debaty na przedsiębiorczość społecznq jako pola badawczego. Bardzo niewiele wiadomo na temat konsekwencji wielorakiego rozumienia przedsiębiorczości społecznej dla ludzi pracujqcych $w$ tym sektorze $i$ innych interesariuszy. Niniejsza praca poświęcona jest opisowi badania jakościowego, które miało na celu pokazanie co pracownicy sektora przedsiębiorczości społecznej w Anglii sqdzq na jej temat i jak postrzegajq jej niejasne granice. Wyniki pokazujq, że w Anglii funkcjonujq trzy różne koncepcje przedsiębiorczości społecznej. I choć wszyscy zgadzajq się na obecność debaty definicyjnej, to opinie na temat konsekwencji dla tego sektora jest kilka. Niektórzy członkowie uważajq, że niesie to ze sobq pozytywne konsekwencje, część uważa raczej odwrotnie, a jeszcze inni uważajq, że debata ta nie ma większego znaczenia.
\end{abstract}

Słowa kluczowe: przedsiębiorczość społeczna, definicje, przedsiębiorstwo społeczne, przedsiębiorca społeczny, UK, Anglia.

\title{
Biographical note
}

Tanya Collavo is a Ph.D. student in Management Research at Said Business School, Oxford University, where she studies brokerage and institutional strategies in the social entrepreneurship sector. Her research interests focus on the theoretical intersection between networks and brokerage and institutional theory, with specific emphasis on new sectors such as social entrepreneurship, the sharing economy or sustainable business. She currently serves as teaching assistant for the MBA Rethinking Business course and as tutor for the undergraduate course in Strategy and Innovation. 